\title{
THE DIACHRONY OF COMPLEX PREDICATES IN DUTCH: A CASE STUDY IN GRAMMATICALIZATION*
}

\author{
CORRIEN BLOM - GEERT BOOIJ
}

\begin{abstract}
This paper investigates the grammaticalization of words into prefixes, via the intermediate stage of separable particles. Particle-verb combinations are analysed as constructional idioms, whereas prefixed verbs are analysed as words.

We hypothesize that semantic change triggers the structural change of particles becoming inseparable prefixes. In this way, syntax reflects semantics: the loss of independent semantic content, accompanied by other specific semantic developments, triggers the loss of syntactic independence. Data from Middle and Modern Dutch are discussed to illustrate the validity of the hypothesis and to show that semantic changes indeed precede syntactic changes in the development of particles into prefixes.
\end{abstract}

\section{Introduction}

Many languages have preverb-verb combinations that function as complex predicates, but are not prefixed verbs. We find such complex predicates in Dutch, in other Germanic languages like German (Stiebels-Wunderlich 1994; Lüdeling 1999), in many Indo-European languages (Watkins 1964), in FinnoUgric languages such as Hungarian and Estonian (Ackerman-LeSourd 1997), and in Caucasian languages such as Udi (Harris 2003). They form a subset of the class of phrasal predicates discussed in Ackerman-Webelhuth (1998).

Modern Dutch complex verbs are traditionally classified as separable (Separable Complex Verb, SCV) or inseparable (Inseparable Complex Verb, ICV). The following sentences illustrate the use of SCVs, both with SOV word order (embedded clauses) and with SVO word order (main clauses) (cf. Booij 2002a;b): ${ }^{1}$

* We would like to thank the anonymous reviewers for their valuable comments on an earlier version of this paper.

1 In the examples, the particles/prefixes and the verbs are underlined.

1216-8076/03/\$20.00 (c) 2003 Akadémiai Kiadó, Budapest 
(1) (a) ... dat Hans zijn moeder opbelde / Hans belde zijn moeder op that Hans his mother up-phoned / Hans phoned his mother up '(that) Hans phoned his mother'

(b) ... dat de fietser neerstortte / De fietser stortte neer that the cyclist down-fell / The cyclist fell down '(that) the cyclist fell down'

In the first example, the word op 'up' that combines with the verb is also used as an adposition. In that case, the non-verbal element is also referred to as a particle, and the SCV is then referred to as a particle verb. Particle verbs form a productive class of SCVs. In the second example, the word neer 'down' is also used as an adverb. The fact that SCVs are felt as word-like units is reflected by Dutch orthography, which requires SCVs to be written as one word, without internal spacing, if the two constituents are adjacent.

The basic reason why SCVs have to be considered as word combinations, and not as prefixed words, is that they are separable: in main clauses, the tensed verbal form appears in second position, whereas the other part is stranded. If we assumed SCVs to be words, we would violate the principle of Lexical Integrity that says that syntactic rules cannot refer to elements of morphological structure (Bresnan-Mchombo 1995; Lapointe 1980).

A second phenomenon in which we see the separability of SCVs is Verb Raising. If the verb of an embedded clause is raised to the matrix clause, the SCV can be split, but it can also be treated as a unit.

(2) (a) ... dat Hans[zijn moeder opbellen $]_{S}$ wilde that Hans his mother up-phone wanted

(b) ... dat Hans zijn moeder wilde opbellen that Hans his mother wanted up-phone

(c) ... dat Hans zijn moeder op wilde bellen that Hans his mother up wanted $\overline{\text { phone }}$

All meaning 'that Hans wanted to phone his mother'.

In sentence (2b) the whole SCV opbellen is raised to the matrix clause, whereas in sentence (2c) the particle $o p$ is left behind in the embedded clause. This means that either the verb bellen only, or the whole SCV opbellen can be raised to the matrix clause, and shows that there is certainly a level at which the SCV does form a unit for the syntax. The conclusion from sentences like (2b) that SCVs can behave as syntactic units is supported by the behaviour of SCVs in the progressive construction 'aan het + infinitive'; compare:

(3) (a) Hans is zijn moeder aan het opbellen Hans is his mother at the up-phone 
(b) ?Hans is zijn moeder op aan het bellen Hans is his mother up at the phone

(c) *Hans is aan het zijn moeder bellen Hans is at the his mother $\overline{\text { phone }}$

(d) Hans is zijn moeder aan het bellen Hans is his mother at the $\overline{\text { phone }}$

All meaning 'Hans is phoning his mother'.

Whereas opbellen can appear after aan het without being split, this is not the case for the VP zijn moeder bellen, which cannot appear after aan het.

The separability of SCVs also manifests itself in the location of the infinitival particle te that occurs between the two constituents of SCVs, as in op te bellen, and in the form of the perfect/passive participle, with the prefix ge- in between the particle and the verbal stem: opgebeld. In derivational morphology, SCVs behave similarly; for instance, the ge-nominalisation of opbellen is opgebel.

A number of these particles also function as real prefixes, i.e., as bound morphemes that cannot be separated from the verb. These prefixed verbs carry main stress on the verbal stem, not on the prefix, whereas the SCVs carry main stress on the non-verbal constituent. Examples are given in (4).

(4) $\mathrm{SCV}$

dóorboor 'to go on drilling'

ómblaas 'to blow down'

ónderduw 'to push under'

óverzet 'to take across'

\author{
PREFIXED VERB \\ doorlóop 'to intersect' \\ omslúit 'to enclose' \\ ondermíjn 'to undermine' \\ overkóm 'to happen to'
}

The meaning of an SCV is often not fully predictable. This semantic unpredictability of SCVs is nicely illustrated by the different SCVs for the verb vallen 'to fall' which exhibits a bewildering variety of meanings, in most cases without a meaning constituent that corresponds to the meaning of the verb vallen:

(5) aanval 'to attack', afval 'to lose weight', bijval 'to applaud', inval 'to invade, to set in', meeval 'to turn out better than expected', omval 'to fall down', opval 'to draw attention', tegenval 'to disappoint', toeval 'to come into the possession of'

A second important observation is that SCVs freely feed deverbal word formation. Normally, derivation is only fed by words, not by phrases, and this is taken by those linguists who advocate a morphological analysis of SCVs as evidence for the word-status of SCVs (Booij 2002a;b): 
(6) DEVERBAL SUfFiXATION:

aanbied 'to offer' - aanbieder 'offerer', aanbieding 'offer'

DEVERBAL PREFIXATION:

invoer 'to introduce' - herinvoer 'to reintroduce'

COMPOUNDING WITH VERBAL LEFT CONSTITUENT:

doorkies 'to dial through' - doorkiesnummer 'direct number'

However, it is not the case that syntactic constructs can never feed word formation: both compounding and affixation may be fed by units that are larger than one word.

Another important observation concerning particle verbs is that the addition of a particle may change the syntactic valency of the verb. In many cases, the SCV is transitive, whereas the verb itself is intransitive. Again, the Projection Principle implies that changes in syntactic valency must be due to lexical operations. The following examples from Booij (2002b) illustrate the valency change effect:

(7) bel (optionally transitive) 'to phone' juich (intransitive) 'to cheer'

iemand opbel 'to phone somebody' loop (intransitive) 'to walk'

As we will see in the next section, an adequate account of the properties of SCVs presented above requires the introduction of the notion 'constructional idiom'.

\section{SCVs as constructional idioms}

The notion 'constructional idiom' as defended in Jackendoff (1997) and in the tradition of construction grammar can be used to do justice to both the syntax-like and the morphology-like properties of SCVs (Booij 2002a). The basic claim is that SCVs all conform to the following syntactic structure scheme:

(8) $\left[X[]_{\mathrm{v}}\right]_{\mathrm{V}^{\prime}}$ where $X=\mathrm{P}, \mathrm{Adv}, \mathrm{A}$ or $\mathrm{N}$

By assigning a $\mathrm{V}^{\prime}$-node to SCVs, we represent their phrasal nature, and hence their syntactic separability. The node $\mathrm{V}^{\prime}$ indicates a first level of projection above the V-node. It cannot be equated with the VP-node in the classical sense, because we must be able to distinguish between SCVs and VPs that contain NPs: in standard Dutch, VPs of embedded clauses cannot be raised to 
their matrix clauses, unlike SCVs. Note, furthermore, that the left constituent is a single lexical category, and does not form a phrase. This correctly implies that particles cannot be modified.

A potential additional argument for the non-projecting status of particles is that they are not easily topicalized. If it is only phrases that are topicalized, the reluctance of particles to be topicalized follows from their not heading an XP. However, as argued by Hoeksema (1991a;b), there are examples of particle topicalization of the SCVs opgaan 'to rise' and uitvoeren 'to export', for instance:

(9) (a) Óp gaat de zon alleen in het oosten

up goes the sun only in the east

'The sun only rises in the east.'

(b) Úit voert Angola veel koffie $\overline{\text { out }} \overline{\text { drives Angola a lot of coffee }}$ 'Angola exports a lot of coffee.'

It appears that the crucial condition for topicalization is not that of phrasal status, bur rather that of contrastive meaning: the particle op in opgaan 'to rise' can be contrasted with the SCV ondergaan 'to set'. Similarly, uitvoeren 'to export' can be contrasted to invoeren 'to import'. In the case of opbellen 'to phone' there is no semantically contrasting particle for $o p$ available, and hence topicalization of this $o p$ is impossible. The non-phrasal status of particles that we assume here remains relevant, though, because it explains why topicalization is only possible under very specific circumstances.

In scheme (8), the verbal position is open, and can in principle be filled by any verb. The non-verbal constituent, however, is specified. That is, there are as many different constructional idioms of this kind as there are words that can fill the left position. For instance, Dutch has the following constructional idioms:

(10) $\left[[\text { af }]_{\mathrm{P}}[\mathrm{x}]_{\mathrm{V}}\right]_{\mathrm{V}^{\prime}}$

$\left[[\text { door }]_{\mathrm{P}}[\mathrm{x}]_{\mathrm{V}}\right]_{\mathrm{V}^{\prime}}$

$\left[[\text { op }]_{\mathrm{P}}[\mathrm{x}]_{\mathrm{V}}\right]_{\mathrm{V}^{\prime}}$

that give rise to particle verbs that begin with af, door, and op respectively, with a fixed terminal node for the particle constituent. Each particle may impose semantic constraints on the kind of verbs it combines with. This proposal has two advantages. First, the notion 'particle' has no role outside the constructions under discussion here, and therefore the words af, door and op need not be listed as particles in the lexicon. Secondly, if a specific particle 
verb combination is not productive, we will not have the corresponding constructional idiom in the lexicon, but only a list of the individual particle verbs of that type. Note that there are also cases where the verb only occurs in the SCV-construction, cases like nabootsen 'to imitate' and omkukelen 'to fall down'. These are lexical idioms, with all terminal nodes fixed.

For each constructional idiom of this kind, its meaning will also be specified. For instance, the meaning of the constructional idiom door-V will be specified as 'to go on V-ing', and the constructional idiom af-V will be specified as 'to finish V-ing'.

\section{Grammaticalization}

Many of the words designated here as particles also occur as preposition, postposition, or adverb. From a historical point of view, they are presumably all adverbs that developed on the one hand into adpositions, and on the other hand into particles. The relevant generalisation appears to be (Booij 2002b) that only those words function as particles that can function as predicates in combination with the verb zijn 'to be'. For instance, the preposition met 'with' cannot be used as a predicate, whereas the adverb/postposition mee with the same meaning 'with' can be used as such, witness the following sentences:

(11) (a) Jan is ook *met / mee

John is also with

'John has joined.'

(b) Ik ga met mijn vader mee

I go with my father with

'I will accompany my father.'

Here is a list of adpositions/adverbs that can be used as predicates, and also function as particles:

(12) PREPOSITIONS:

aan 'at', achter 'behind', bij 'at', binnen 'inside', boven 'above', buiten 'outside', na 'after', om 'around', onder 'under', tegen 'against', voor 'for'

PREPOSITIONS/POSTPOSITIONS:

door 'through', in 'in', langs 'alongside', op 'up', rond 'round', over 'over', uit 'out', voorbij 'past'

POSTPOSITIONS:

af 'down', heen 'towards', mee 'with', toe 'to', 'shut' 
The following list provides examples of the use of each of these particles:

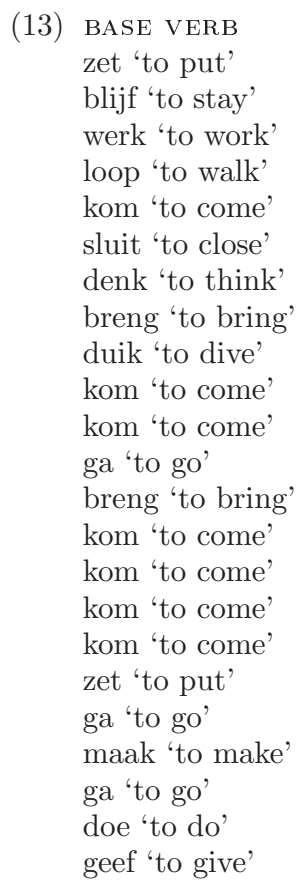

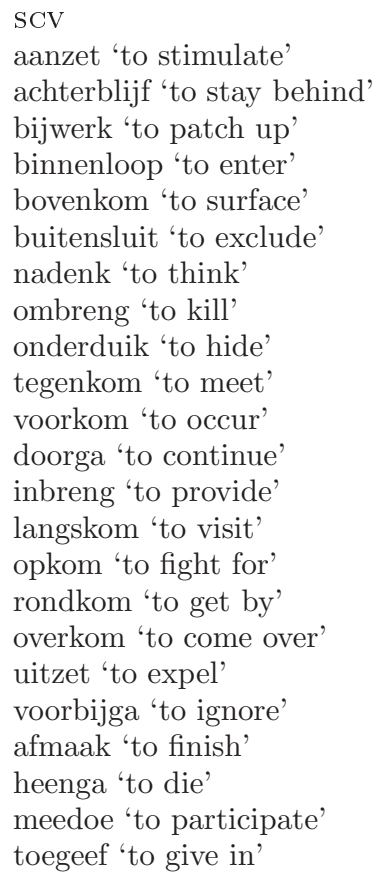

This restriction on the words that can be used as particles can be seen as a reflection of the origin of the particle verb construction: it is a grammaticalization of a syntactic configuration with secondary predication. For instance, the sentence Jan maakte zijn huiswerk af 'John finished his homework' can still receive a syntactic interpretation, with the predicate of functioning as a secondary predicate. That is, this sentence can receive the same structural analysis as the sentence Jan verfde zijn fiets wit 'John painted his bike white'. In many cases, however, the meaning of particles such as af has bleached, and the particles have acquired a mainly aspectual value. For such cases, we have to assume that the predicate-verb combination has grammaticalized into a particle verb construction. In other words, the particle verb construction is the result of reanalysis of syntactic configurations with secondary predication, in syntactic contexts where the words are adjacent, that is, in embedded clauses. For instance, in the clause ...dat Jan zijn huiswerk af maakte, the word af forms a predicate phrase together with zijn huiswerk, but it can be reinterpreted as part of a particle verb afmaak that has zijn huiswerk as its direct object. Thus, these observations illustrate two properties of grammat- 
icalization (Hopper-Traugott 1993, 17): “(a) earlier forms may coexist with later ones [...]; (b) earlier meanings may constrain later meanings and/or structural characteristics". Particles may subsequently grammaticalize further and become (inseparable) prefixes.

It may be useful to stress here that we see grammaticalization as being an effect of mechanisms of language change such as reanalysis, not as a type of change in its own right. In other words, we use the term 'grammaticalization' as a convenient descriptive term for the phenomenon that lexical items become grammatical items, and grammatical items become even more grammatical. That also means that unidirectionality is taken to be a defining property of grammaticalization, not a refutable empirical hypothesis about grammaticalization (cf. Campbell 2001). The empirically refutable hypothesis that we defend in this paper is that particular semantic changes, such as bleaching, the becoming more abstract of the meaning of words, can be seen as the trigger (but not as a sufficient or necessary condition) for this grammaticalization development (this hypothesis will be worked out in 4.1).

The second class of SCVs that we mentioned above are those with words that are also used as adverbs but not as adpositions, such as:

(14) neer 'down', samen 'together', terug 'back', thuis 'home', weg 'away'

In these cases, it is the combination of verb and adverb that is reanalysed as a unit. For instance, in the sentence Hij legde het boek weg 'He put the book away' it is the combination weg leggen that has the syntactic valency of a transitive verb, for which het boek functions as direct object: the sentence *Hij legde het boek 'He put the book', without the adverb, is ungrammatical.

The phenomenon of grammaticalization can be circumscribed as: "[...] the process whereby lexical items and constructions come in certain linguistic contexts to serve grammatical functions, and, once grammaticalized, continue to develop new grammatical functions" (Hopper-Traugott 1993, xv). This is indeed what we observe for particle verbs: they are syntactic constructs that function as complex verbs with a number of aspectual properties, and thus developed into constructional idioms.

From the point of view of grammaticalization particles might be seen as intermediate stages in the development of words into bound morphemes, in particular, prefixes. Some particles are also used as inseparable prefixes, as is illustrated in (4), repeated here as (15). 
(15) SCV

dóorboor 'to go on drilling'

ómblaas 'to blow down'

ónderduw 'to push under'

óverzet 'to take across'

\author{
ICV \\ doorlóop 'to intersect' \\ omslúit 'to enclose' \\ ondermíjn 'to undermine' \\ overkóm 'to happen to'
}

Our hypothesis is that the change from particles into prefixes involves the loss of independent semantic content and that prefixes impose a holistic interpretation on the complex verb, i.e., the direct object of a prefixed verb is always completely affected by the event expressed by this complex verb. Particles, on the other hand, may or may not have concrete meanings and do not necessarily impose a holistic interpretation on the complex verb. In sum, the following historical development might be hypothesized for Dutch:

(16) word $>$ particle $>$ prefix

Some morphemes belong to more than one of these categories, for example:

(17) (a) WORD AND PARTiCle: af, neer 'down', op 'up'

(b) WORD, PARTICLE, AND PREFix: achter 'behind', door 'through', mis 'wrong', om 'around', vol 'full'

The prefixes be- and ver-derive historically from the words $b i$ (Modern Dutch bij 'at') and faur/fair/fra (Modern Dutch voor 'for') respectively, whereas bij and voor function as prepositions and as particles.

The hypothesis that the SCV system may function as an intermediate stage in the grammaticalization of syntactic constructs into morphological constructs is supported by the observation that a number of verbs which were still SCVs in Middle Dutch, have developed into ICVs in Modern Dutch. This applies to, for instance, the following verbs:

(18) achtervolg 'to run after', omring 'to surround', omsingel 'to surround', overbrug 'to bridge', overval 'to attack suddenly' (source: van Loey 1976)

As the glosses of these examples show, the preverbal elements, originally locational prepositions or adverbs, are semantically bleached and impose a holistic interpretation on the complex verb (the 'affectedness reading') in their uses as inseparable prefixes. That is, we hypothesize that the loss of word status of the particles is triggered by these semantic developments. The following examples serve to illustrate the use of the more concrete, spatial interpretation of these verbs in Middle Dutch, which correlates with separability of overbruggen and omringen: 
(19) (a) Voort gheven wy hem oorloff eene nieuwe havene te graven ende die over further give we him permission a new harbour to dig and that over te brugghen to bridge 'Furthermore, we give him permission to dig a new harbour, and to put a bridge across it.' (Van Loey 1976, 124)

(b) Mettien hebben sise ommegeringhet immediately have they-her around-ge-rounded 'Immediately, they surrounded her.' (Van Loey 1976, 90)

Another example supporting this hypothesis is given in (20):

(20) ende heeft den almoghende Godt aengebeden and has the almighty God at-ge-prayed 'and prayed to the almighty God' (Hist. Malegijs, 1. 1556)

In (20) áenbidden 'to pray to' is separated by the present perfect marker ge-. This Middle Dutch SCV must be distinguished from the Middle Dutch ICV anbéden 'to adore' (MNW 1998). In accordance with our hypothesis, the meaning of the separable particle aan in áenbidden is more concrete (directional) than that of the inseparable prefix aan in anbéden. In Modern Dutch, only the ICV aanbidden is left, with the meaning of the Middle Dutch ICV anbéden 'to adore'.

As noted by van der Horst and van der Horst $(1999,348)$, there is also a number of verbs that were used as separable in 18th and 19th century Dutch, and that are now inseparable, thus instantiating the same development as took place in Middle Dutch, verbs such as voorkomen 'to prevent' and doorstaan 'to endure'. In sum, we hypothesize that the preverb position of SCVs can form an intermediate step in the development of words into prefixes.

Let us point out here that we do not claim that semantic bleaching always causes the particles to become prefixes. This is clearly not the case: as the examples in (13) show, there are plenty of SCVs with particles that have lost their spatial interpretation, but do not show any tendency to become prefixed verbs. In this respect there is a similarity with the use of auxiliaries in periphrastic tenses, which do not develop into bound morphemes although the meaning of these verbs has certainly bleached. What we do claim is that when words or particles become prefixes, semantic change is the trigger.

In the next section, we will investigate and substantiate this hypothesis in more detail, by looking at two particles/prefixes in Middle and Modern Dutch. 


\section{Two test cases: the development of the prefixes door and over}

\subsection{Introduction}

To test our hypothesis, we looked at Middle and Modern Dutch data of complex verbs with door 'through', 'on', and over 'over'. The reason for choosing these two particles/prefixes is that they productively form both SCVs and ICVs, which is only the case for a small subset of the Dutch preverbs. ${ }^{2}$ Examples of these two preverbs, both in SCVs and in ICVs, are given in (21).

(21) SCV

dóorboor 'to go on drilling'

dóorsnijd 'to cut in two'

óverzet 'to take across'

óvergooi 'to throw over'

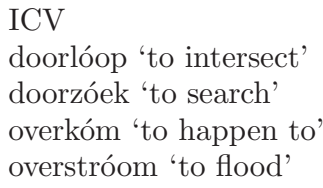

ICV

doorlóop 'to intersect'

doorzóek 'to search' overkóm 'to happen to' overstróom 'to flood'

Some general remarks regarding the data have to be made. First, the term 'Middle Dutch' does not refer to an established language; it is a collective term for all dialects spoken in the Low Countries between roughly 1200 and 1600. Because of the fact that there was no standard language yet, many differences between these dialects exist. Besides this geographical variety in the data, there is diachronic variety, since the Middle Dutch period comprises almost four centuries.

We only looked at prose texts, since in poetry word order might be influenced by rhyme demands (Los 2002). It is important to note that the genres left from the Middle Dutch era vary over periods. That is, the oldest texts appearing in the Dutch language are legal documents, written in an official style (1200-1350), whereas religious and scientific texts developed somewhat later (1300-1400). Only from 1400 on, narrative prose texts were written in reasonable numbers. As shown in Blom (2002), large textual differences exist between official, religious, and narrative texts; the most reliable data, regarding word order, seem to be found in narrative texts. Therefore, we excluded data from official and religious texts. In addition to the relatively late narrative texts, we selected a few scientific texts from earlier periods.

We took 13 texts from the CD-rom Middelnederlands, a collection of Middle Dutch texts, and selected from these texts all complex verbs with

2 By 'preverb' we refer to both particles and prefixes, that is to say to the uses of door and over in complex verbs, regardless of their (in)separability. 
door and over. ${ }^{3}$ Next, we classified these verbs as SCV or ICV on the basis of the types of evidence mentioned in section 1 and briefly repeated here.

Evidence for SCV status is the separation of the particle and the verb, which can be caused by Verb Second movement, by the position of the infinitival marker $t e$, by the participial marker ge- (in Middle Dutch also written as ghe-), or by one or more other verbs, such as auxiliaries and modals. Middle Dutch corpus data in which these factors were attested are given in (22)-(25). ${ }^{4}$

(22) Oriande die in grooter vreesen was ginc vast door (VI-179a1)

Oriande who in big fear was went steadily on

'Oriande who was afraid went on steadily'

(23) om dan over te reysen na Eggermont (VI-59a)

for then across to travel to Eggermont

'to travel then further to Eggermont'

(24) Ende si werden van achteren doer gereden (I-159rb)

and they were from behind in-two ge-driven

'and they were driven apart from behind'

(25) ende hi alle dinc guetelic ouer laet lijden (II-35b)

and he all things in-a-good-way over let pass

'and he let all things pass by in a good way'

An additional separator in Middle Dutch is the negative particle ne/en. An example with this separator is given in (26).

(26) dat ghi dat hersenbeckin niet dore ne bort (VIII-33)

that you the skull not through ne $\overline{\text { drill }}$

'that you do not drill the skull in two'

In Modern Dutch, this negative particle does not exist anymore.

Evidence for ICV status is the absence of separation, which can be observed in clauses in which both the preverb and the verb occur in Verb Second position (27) and in clauses in which the infinitival marker te precedes both the preverb and the verb $(27) .^{5}$

3 The titles, sources, and lengths of these texts are given in the references.

4 In the corpus examples the Roman number refers to the text number. This number is followed by the paragraph number in the relevant text.

${ }^{5}$ It should be noted that the presence or absence of a space between the preverb and the base verb does not give any evidence for respectively SCV- or ICV-hood of the relevant verb in Middle Dutch, since there were no orthographic conventions regarding this issue in the Middle Dutch period. 
(27) ende hi doer stack hem daer hi hinc aen die mure (I-150vb) and he through pierced him when he hung on the wall

'and he stabbed him completely through when he hung on the wall'

(28) ende meende hem te door rijden (VI-36a)

and intended him to through drive

'and intended to run him over completely'

If an auxiliary or modal is present, but does not cause separation of the particle and the verb, as shown in (29)-(30), this does not give conclusive evidence for the ICV status of the complex verb in question, since auxiliaries and modals appear before and after the whole preverb-verb complex in both SCV and ICV constructions.

(29) dat hy daer mede vrijlijcken door passeren soude (VI-124)

that he there with freely through pass would

'so that he would freely pass through with it'

(30) of si soude dye stadt moeten overgeven (VI-56b)

or he should the town must away-give

'otherwise they should have to give the town away'

It thus follows that the word orders auxiliary-preverb- $\mathrm{V}$ and preverb- $\mathrm{V}$-auxiliary do not give either SCV or ICV evidence. If, on the other hand, auxiliaries and modals separate the preverb from the verb (preverb-auxiliary-V), as in (25) above, this is unambiguous SCV evidence.

In Middle Dutch, the position of the participial marker ge- (or ghe-) cannot straightforwardly be taken as evidence for ICV-status either. With respect to ge-it must be noted that in Modern Dutch verbs with an unstressed prefix have perfect/passive participles without ge-, as shown in (31). In the corresponding SCV, on the other hand, given in (32), ge- is present. The absence of $g e-$, in clauses such as (31), then, can be taken as ICV evidence.

(31) hij heeft het hele land doorkruíst

he has the whole country through-crossed

'he has intersected the whole country'

(32) hij heeft de taart doorgesneden

he has the cake through-ge-cut

'he has cut the cake through/in two'

In Middle Dutch, however, the participial prefix ge- is often omitted, both in simplex and in complex verbs. Therefore, the absence of $g e$ - between a preverb and a verb as such cannot be taken as unambiguous ICV evidence. 
If, on the other hand, all other participial forms in the relevant text show consistent participial marking, we do take the absence of $g e$ - in a complex verb to be ICV evidence.

Another type of construction from which no unambiguous SCV- or ICVhood can be deduced concerns finite verb forms in subordinate clauses. In Dutch subordinate clauses the finite verb is in clause-final position and in this position the preverb always precedes the base verb: nothing can intervene between these two parts, neither in SCVs, nor in ICVs. The same holds for infinitival forms without te, which always appear clause-final and show the order preverb-verb, without separator. In these verbal forms, only stress can disambiguate between SCVs and ICVs, since main stress is on the particle in SCVs and on the verb in ICVs (see also section 1). Since we only have written sources from Middle Dutch, Middle Dutch finite verb forms in subordinate clauses and infinitives without te cannot be disambiguated. Examples of these two constructions are given in (33)-(34).

(33) ende sach dat nesteus op hem quam die hem sinen helme doersloech (I-152rb)

and saw that Nestus up him came who him his helmet through-stroke

'and saw that Nestus came up to him who pierced through his helmet'

(34) Ic hebbe enen enighen soen dien ic v luden beuelen ende ouerleueren wil (II-02a)

I have an only son who I you men recommend and over-carry want

'I have only one son whom I want to recommend and to give to you'

Our general hypothesis is that there is a relation between the syntactic status and the semantic content of a preverb: if the preverb is a prefix, it will show the typical semantic property of imposing an affectedness reading on the complex verb. This hypothesis can be worked out both synchronically and diachronically.

Synchronically, we expect that an ICV imposes a holistic interpretation on the complex verb, whereas an SCV does not necessarily do so. SCV preverbs, then, show other semantic effects than this affectedness effect. We will check this synchronic hypothesis for both Modern and Middle Dutch. Diachronically, i.e., in comparing Middle and Modern Dutch data, we expect the loss of independent syntactic status of a preverb to go hand in hand with a loss of independent semantic content (i.e., semantic bleaching). Thus, Middle Dutch SCVs may develop into Modern Dutch ICVs and if they do, the Modern Dutch ICV will show the affectedness reading, whereas the Middle Dutch SCV does not necessarily do so. We do not expect Middle Dutch ICVs to develop into Modern Dutch SCVs, since this would involve the isolation of a formal and semantic unit (the preverb) out of the ICV (as a particle has more 
independent syntactic status and semantic content than a prefix). Because of the fact that the ICV as a unitary whole has the holistic interpretation and expresses the affectedness of the direct object, it is very unlikely that a part of it will, in a later stage, split off as a consequence of having gained more independent meaning of its own. Thus, Middle Dutch SCVs may develop into Modern Dutch ICVs, but Middle Dutch ICVs are not expected to develop into Modern Dutch SCVs.

\subsection{Results}

\subsubsection{General results}

In our corpus, which contains 476,000 word tokens, we found 47 different complex verbs with door and 43 different complex verbs with over (lemmas, types). Some of these types occur more than one time, so that our complete corpus contains 226 tokens, of which 112 are complex verbs with door and 114 with over. 32 complex verbs with door occur only once, and the same holds for 19 complex verbs with over.

Only about $60 \%$ of these complex verbs can unambiguously be classified as either SCV or ICV. Most of the remaining complex verbs are finite verbs in the sentence final position of subordinate clauses, such as the ones in (33)-(34) above, from which it cannot be deduced whether the relevant verb is separable or not. These items, then, do not give us either SCV or ICV evidence.

Some types of complex verbs that are attested by several tokens give contradictory syntactic evidence. This is to say, some of their tokens are syntactically separated and others are unambiguously not separated (for example, the preverb and the verb occur together in V2 position). Instead of there being no SCV or ICV evidence at all, the types in this category show both SCV and ICV evidence. These complex verbs will be discussed in section 4.2.4.

Looking at the different types of complex verbs, the distribution over SCVs, ICVs, verbs that show both SCV and ICV evidence (labelled 'SCV+ ICV'), and verbs that do not show any explicit SCV or ICV evidence at all (labelled 'SCV/ICV'), accompanied by the horizontal percentages, is given in Table 1.

As Table 1 shows, both SCVs and ICVs with door and over occur in Middle Dutch, although the number of the verbs we could unambiguously classify as either SCV or ICV is relatively small. 
Table 1

Distribution over SCVs, ICVs, SCV+ICVs, and SCV/ICVs

\begin{tabular}{lccccc}
\hline & SCV & ICV & SCV +ICV & SCV $/$ ICV & TOTALS \\
\hline DOOR & $10(21 \%)$ & $22(47 \%)$ & $2(4 \%)$ & $13(28 \%)$ & $47(100 \%)$ \\
OVER & $12(28 \%)$ & $10(23 \%)$ & $6(14 \%)$ & $15(35 \%)$ & $43(100 \%)$ \\
Totals & $22(24 \%)$ & $32(36 \%)$ & $8(9 \%)$ & $28(31 \%)$ & $90(100 \%)$ \\
\hline
\end{tabular}

\subsubsection{Synchronic results}

\subsubsection{Modern Dutch preverbs}

Inspection of Modern Dutch SCVs and ICVs with productive uses of door and over reveals important semantic differences between the separable preverbs on the one hand and the inseparable ones on the other. These differences are summarized in (35)-(36).

(35) Door - SCVs

1. continuation: dóorfietsen on-cycle 'to go on cycling'

2. with force or speed: dóorlopen on-walk 'to walk firmly/quickly'

3. split, separation: dóorsnijden through-cut 'to cut in two'

4. movement (path) through: het land dóorreizen through-travel 'to travel through the country'

Door - ICVs

1. to V completely through: doorbóren through-drill 'to stab, to perforate'

2. to soak completely: doordrénken through-drench 'to drench'

\section{(36) Over - SCVs}

1. movement (path) to the other side: óverzetten over-put 'to take across'

2. to be left, to remain: óverblijven over-remain 'to be left over'

3. again: óverdoen over-do 'to do again'

4. imitation: óverschrijven over-write 'to copy'

\section{Over - ICVs}

1. completely covering sth. by moving over it (literally or figuratively): overspoélen over-wash 'to wash over', overdénken over-think 'to reflect on'

2. too much: overschátten over-value 'to overestimate'

The lists in (35)-(36) show that, although the meanings of the particles and the prefixes are sometimes closely related, there is an important difference between the two: whereas the particles show different meanings with relatively independent semantic content (often lexical and spatial, but sometimes more aspectual meanings), the prefixes show a uniform semantic effect: they impose a holistic interpretation on the complex verb. This appears from the 
translations of the ICV meanings, involving the complete affectedness of the direct object. A direct object (Theme), then, must be present in utterances with ICVs, which explains the fact that ICVs are always transitive (or unaccusative). The total affectedness of the direct object results in telicity: ICVs always express telic situations. SCVs, on the contrary, can be transitive and telic too, but they are not necessarily so (see, for instance, the SCV categories door 1 'continuation', door 2 'with force or speed', and over 2 'to be left, to remain').

The first meaning of separable door ('continuation') is the clearest example of a preverb forming non-holistic, intransitive, and atelic SCVs. This particle has a merely aspectual meaning that is assumed to constitute a metaphorical extension of the path meaning of separable door. If one applies the path meaning to the notion of time instead of space, this results in the relevant durative meaning.

The Modern Dutch data in (35)-(36) thus confirm the synchronic hypothesis regarding the relation between the semantic contribution of the preverb and its syntactic separability: inseparable prefixes impose a holistic interpretation on the complex verb: the direct object is totally affected. These prefixes have less independent meanings than the separable particles of SCVs. In SCVs, on the other hand, the particle does not (necessarily) impose a holistic interpretation on the complex verb.

\subsubsection{Middle Dutch preverbs}

A synchronic look at the semantic content of the Middle Dutch separable preverbs door and over reveals a similar result as we saw for Modern Dutch: most SCV-particles have independent semantic content, whereas ICV preverbs do not. ICV preverbs, then, form more of a semantic unit with their verbs and these ICVs express, as unitary wholes, the total affectedness of the direct object. This is the case for 9 of the $10 \mathrm{SCVs}$ with door and for 10 of the $12 \mathrm{SCVs}$ with over.

In its concrete function Middle Dutch door denotes a path, as illustrated in (37), a split or separation, as in (38), or can be paraphrased as 'to go on V-ing' or 'to V firmly/quickly', as in (39). All these meanings are also available in Modern Dutch, as we saw above.

(37) also mense eet so comtse beneden dore (XII-99a)

as one-it eats so comes-it below through

'the way that one eats it, it comes through below' 
(38) Ghi selt nemen .1. sceers ende sniden die huut dore (VIII-68) you should take a knife and cut the skin through 'You should take a knife and cut the skin through.'

(39) Oriande die in grooter vreesen was ginc vast door (VI-179a1) Oriande who in big fear was went steadily on 'Oriande who was afraid went on steadily.'

In one SCV with door the particle imposes a holistic interpretation on the complex verb and thus resembles ICV prefixes. The relevant construction is given in (40).

(40) Had een minsche al sijn leven doergelevet wael ende gotliken (XIII-180) had a man all his life through-ge-lived good and religious 'if a man had lived all his life in a good and religious way'

The meaning of doorleven in (40), 'to live all his life, to live his life completely/to the end', is holistic and the particle of this complex verb does not have a clearly independent semantic content. According to its meaning it can be said to belong to the first category of the ICV meanings with door in (35). In fact, the Modern Dutch counterpart of this verb (with the same meaning) is inseparable: doorléven. So it seems as if in the Middle Dutch verb dóorleven the meaning of the preverb door has already bleached, but this has not yet led to a change in formal structure. In Modern Dutch, however, this change has taken place: the SCV has become an ICV.

This shows that the semantic changes (leading to bleached semantics and the affectedness reading) indeed precede the formal change, in accordance with our hypothesis. The semantic and formal changes that are involved in the process of becoming a prefix show that there is a higher degree of cohesion between the preverb and the verb in ICVs than there is in SCVs, which reflects the fact that preverb and verb have become a closer unit semantically.

Next, we look at Middle Dutch SCVs with over. Separable over denotes a (literal or figurative) movement in a certain direction, or something that is left. These meanings, which are also attested in Modern Dutch, are illustrated in (41)-(42).

(41) dat haer here aldus was ouerghecomen (I-152rb)

that their lord thus was over-ghe-come

'that their lord thus had come over'

(42) dat si solden verghaderen die stucke die daer ouer waren ghebleuen that they should gather the pieces that there $\overline{\text { over }}$ were ghe-remained 'that they should gather the pieces that had been left over there'

(IV-187) 
These SCV meanings are present in 10 of the $12 \mathrm{SCVs}$ with over. The other meanings of over that are attested in Modern Dutch, such as 'again' and 'imitation', are not found in the SCVs in our corpus. ${ }^{6}$

We found two SCVs with over with holistic meanings. The relevant constructions are given in (43)-(44).

(43) Doen Oriande den staet $\quad$ over had gesien, heeft si geseyt (...) (VI-203)

when Oriande the situation $\overline{\text { over }}$ had ge-seen, has she said $(\ldots)$

'When Oriande had surveyed the situation, she said (...)'

(44) mer tis een flaute die hem over ghecomen is (VI-56a)

but it-is a swoon that him over ghe-come has

'but it is a swoon that has happened to him'

These constructions are similar to the one in (40), in the sense that the Middle and the Modern Dutch verbs have the same (holistic) meaning, but differ in separability: whereas the Middle Dutch verbs óverzien 'to survey' and óverkomen 'to happen to' are separable, the Modern Dutch verbs overzien and overkómen are not. ${ }^{7,8}$ This can again be explained by assuming that the semantic changes trigger, and thus precede, the syntactic development (see also section 4.2.3).

As opposed to the Middle Dutch SCVs, the Middle Dutch ICVs with door and over mostly have holistic meanings, in which the event is stretched out completely over the Theme. These holistic meanings are also present in the Modern Dutch ICVs with door and over. Since the holistic process expressed by an ICV totally affects the Theme, ICVs are transitive (or unaccusative) and telic. Some Middle Dutch examples of holistic ICVs with door and over are given in (45)-(46).

(45) Ende si doerboorden hare scepe (I-148vb)

and they through-drilled their ships

'and they stabbed their ships'

${ }^{6}$ Of course, this does not necessarily mean that these meanings were not available in Middle Dutch at all.

7 The verb overkomen 'to happen to' also has a non-holistic counterpart, both in Middle and Modern Dutch. In this non-holistic, directional sense, overkomen means 'to come over'. This verb is separable in both language stages and will be discussed in section 4.2.3.

8 If occurring outside the Middle Dutch examples, Middle Dutch verbs are adjusted to the Modern Dutch orthography (e.g. overcomen > overkomen). 
(46) Dus ouerdocht ic dit bi menighen dinghen (V-49)

so over-thought I this by many things

'So I reflected on this in several ways.'

These kinds of holistic readings are available in all ICVs in our corpus (22 with door and 10 with over).

In sum, the meanings found in Middle and Modern Dutch SCVs and ICVs support the synchronic part of our hypothesis, namely that ICV-preverbs impose holistic interpretations on the complex verbs and do not have much semantic independence of their own. ICVs express events by which the direct object is totally affected and this explains why ICVs, but not SCVs, are always transitive (or unaccusative) and telic. The hypothesized synchronic relationship between SCV and ICV preverbs in Middle Dutch, then, is clearly confirmed.

All in all, we can conclude that Middle Dutch and Modern Dutch complex verbs synchronically show the expected relationship between their formal properties and their semantics.

\subsubsection{Diachronic results}

The second aspect of the hypothesis concerns the diachrony: is it indeed the case that Middle Dutch separable particles may develop into Modern Dutch inseparable prefixes that are semantically bleached (i.e., have no independent semantic content anymore) and show the effect of imposing a holistic interpretation on the complex verb, in which the direct object is totally affected by the semantic unit prefix-verb? And is it indeed the case that Middle Dutch ICV prefixes, expressing this semantic effect together with their verbal base, do not develop into separable particles? We will investigate this by comparing our Middle Dutch corpus data with their Modern Dutch counterparts.

Our Middle Dutch corpus contains 10 SCVs with door, listed in Table 2. If the content of these verbs is expressed by the same form in Modern Dutch, the right column shows the label 'id.' ('identical form and meaning'). If, alternatively, another verbal form is used in Modern Dutch to express the relevant semantic content, this other form is given in the right column.

We see that most SCVs with door in our Middle Dutch corpus are still functioning as SCVs in Modern Dutch, expressing the same meanings. The meanings of these verbs have not (yet) changed (the particles (still) have independent meanings, there is no holistic effect), so there is no reason for a change in the syntax of the complex verbs; they remain separable. 
Table 2

Middle Dutch SCVs with door

\begin{tabular}{ll}
\hline MidDle DutCH & Modern DutCH \\
\hline dóorboren 'to drill in two' & id. ('identical form and meaning') \\
dóorgaan 1 'to continue' & id. \\
dóorgaan 2 'to go through' & id. \\
dóorkomen 'to come through' & id. \\
dóorleven 'to live completely through' & doorléven (ICV) \\
dóorrijden 'to separate by riding' & uitéenrijden 'to drive apart' \\
dóorsiën 'to filter through' & dóorfilteren \\
dóorsnijden 'to cut in two' & id. \\
dóorsteken 'to pierce through' & id. \\
dóorwaken 'to wake through' & id. \\
\hline
\end{tabular}

The Middle Dutch SCV dóorleven has developed into a Modern Dutch ICV. In the previous section we saw that this complex verb already has a holistic meaning in Middle Dutch. In this case, then, there is a trigger for a change in the structure of the complex verb. In Modern Dutch, the structure is adapted to the semantic changes. In this complex verb, we see a clear case of the grammaticalization of a particle into a prefix, whereby a syntactically and semantically relatively independent lexical item loses its semantic content and its syntactic independence. The semantic changes in this development precede the syntactic change of becoming inseparable.

Table 2 shows two Middle Dutch SCVs that have been replaced with a different SCV (with the same meaning) in Modern Dutch (dóorsiën - dóorfilteren 'to filter through', dóorrijden - uitéenrijden 'to separate by driving'). These are cases of lexical change. Concerning the first SCV, the word siën does not exist in Modern Dutch anymore, and another form has taken over its function. The second SCV refers to the situation of a crowd that is split up by driving through it. The particle door, then, indicating a split, means 'apart'. In Modern Dutch this particle is replaced with another particle, also meaning 'apart': uiteen. Clearly, the preverbs of both of these SCVs still have SCV meanings (there are no holistic interpretations) and still are separable, so the properties of the verbs that we are interested in here have not changed.

To summarize, most of the Middle Dutch SCVs with door have Modern Dutch SCV counterparts with the same meaning. There is one Middle Dutch SCV with a holistic meaning, and this complex verb has developed into an ICV in Modern Dutch, thereby adapting its structure to the already changed semantic properties. 
Next, we turn to the SCVs with over to see whether we can spot a similar grammaticalization development. Our corpus contains $12 \mathrm{SCVs}$ with over. These SCVs are listed in Table 3, accompanied by their Modern Dutch counterparts.

Table 3

Middle Dutch SCVs with over

\begin{tabular}{ll}
\hline MidDle Dutch & Modern DuTCH \\
\hline óverblijven 'to be left over' & id. \\
óverbrengen 'to take to, to carry over' & id. \\
óvergaan 'to come over someone' & door je héen gaan 'to go through someone' \\
óvergeven 1 'to give to, to give away' & id., only meaning 'to give to' \\
óvergeven 2 'to charge, to instruct' & ópdragen \\
óverkomen 1 'to come to' & id. \\
óverkomen 2 'to happen to' & overkómen (ICV) \\
óverkomen 3 'to pass by' & voorbíjgaan \\
óverleveren 'to carry over, to transmit' & óverdragen \\
óverreizen naar 'to travel further to' & dóorreizen naar \\
óverschieten 'to shoot to the other side' & id. \\
óverzien 'to see completely over, to survey' & overzíen (ICV) \\
\hline
\end{tabular}

Five of the Middle Dutch SCVs with over have the same form (and the same meaning) in Modern Dutch. Their particles still have independent semantic content and do not (yet) impose a holistic interpretation on the complex verb. An important condition for grammaticalization, namely the necessary semantic change, does not seem to be fulfilled.

Table 3 shows that two Middle Dutch SCVs with over have developed into ICVs in Modern Dutch: óverkomen 'to happen to' and óverzien 'to overlook, survey'. As mentioned in section 4.2.2, the particles in these Middle Dutch $\mathrm{SCVs}$ impose holistic meanings on the complex verbs and in this respect, óverkomen and óverzien are similar to dóorleven 'to live completely through, to live to the end', described above. These Middle Dutch separable complex verbs are in the process of developing into inseparable ones; although the meanings of these verbs have already changed into typical ICV meanings, their preverbs are still separable.

The five remaining SCVs have undergone a formal change in the particle and/or the base verb: particle and/or verb are replaced with another form (óvergaan, óvergeven 2 , óverkomen 3 , óverleveren, óverreizen naar). In all of these complex verbs the Middle and the Modern Dutch particles have typical SCV meanings, expressing a literal of figurative movement (path) (see section 4.2.2). None of these SCVs shows the holistic ICV interpretation that 
involves the total affectedness of the direct object, so, again, the characteristics of the complex verbs that are important for us here have not changed.

Turning now to the Middle Dutch ICVs, whose preverbs have already grammaticalized into prefixes at this early stage of Dutch, we expect that these complex verbs still function as ICVs in Modern Dutch, probably with the same form (or an etymologically related form) and the same function. What we do not expect to find is Middle Dutch ICVs that have developed into Modern Dutch SCVs. This expectation is based on our assumption that changes in the semantics of the preverb function as the trigger of changes in its formal status. Therefore, a development from ICV into SCV would imply that holistic prefixes without independent semantic content could develop such semantic content of their own and could isolate this content from the semantic content of the verb, with which they used to form a unitary whole, expressing the semantic content of total affectedness. After this process of semantic isolation, then, would follow a process of formal isolation, resulting in the separability of the, formerly inseparable, preverb. A semantic development as described above, however, is claimed to be impossible.

Our corpus contains $22 \mathrm{ICVs}$ with door. These are, with their Modern Dutch counterparts, listed in Table 4 (see page 84 ).

In conformity with our expectations, there are no Middle Dutch ICVs that have developed into Modern Dutch SCVs.

We see that most of the Middle Dutch ICVs still function as ICVs in Modern Dutch. Some Modern Dutch ICVs have exactly the same form as their Middle Dutch counterparts (e.g. doorbóren, doorzien), but in other cases the original form is replaced with a formally similar, often etymologically related ICV with the same meaning. These Modern Dutch ICVs have another prefix (doorrijden) or another verbal base (doornágelen, doortógen zijn van) than their Middle Dutch counterparts; in most cases the Middle Dutch verbal base has become obsolete. In all complex verbs that show these changes, however, both the Middle and the Modern Dutch ICV unambiguously show the holistic semantics typical of ICVs.

In two cases the prefix door has disappeared (doorscóord zijn, doorwónd $z i j n)$. Both of these ICVs only occur in past participle forms in our corpus, expressing perfective states ('to be cracked', 'to be wounded'). Finally, there are two ICVs that have another prefix in Modern Dutch (doorziën - verzengen 'to scorch', doorstéken - verwonden 'to wound'). Regarding doorziën, the verbal bases of the Middle and the Modern Dutch ICVs may be etymologically related, but the prefix has changed. It should be noted that the prefix ver-forms transitive complex verbs with telic and holistic meanings, so with 
Table 4

Middle Dutch ICVs with door

\begin{tabular}{ll}
\hline MiDDLE DuTCH & MODERN DUTCH \\
\hline doorbóren 'to stab, to pierce' & id. \\
doordrínken 'to soak completely with' & id. (doordrénken) \\
doorgáten 'to pierce' & doorbóren \\
doorgráven 'to pierce by digging', & id. \\
doorhóuwen 'to pierce by striking' & doorsláan \\
doorlópen 'to intersect' & id., doorkrúisen \\
doornágelen 'to pierce with nails' & doorspíjkeren (spijker: 'nail') \\
doorrénnen 'to intersect' & doorkrúisen \\
doorríjden 'to run over/through completely' & overríjden \\
doorríjgen, doorríen 'to pierce' & doorbóren \\
doorríjten 'to pierce' & doorbóren \\
doorscóord zijn 'to be cracked' & gescheurd zijn \\
doorzíen 'to see completely through, to survey' & id. \\
doorsláan 1 'to intersect' & doorlópen, doorkrúisen \\
doorsláan 2 'to pierce' & doorbóren \\
doorsníjden 'to cut through completely, to pierce by & id. \\
cutting' & \\
doorstéken 'to stab completely through, to wound' & id., door en door steken*, verwonden \\
doortógen zijn van 'to be completely soaked with' & doortrókken zijn van \\
doorwándelen 'to go completely through, to undergo' & id. \\
doorwónd zijn 'to be wounded' & gewond zijn \\
doorwórstelen 'to struggle completely through' & id. \\
doorzíën 'to scorch' & verzengen, verschroeien \\
\hline
\end{tabular}

*The Modern Dutch expression door en door means 'completely'.

respect to these properties it is highly similar to inseparable door (the same holds for the prefix be-, which sometimes replaces inseparable over, see the data in Table 5 below). For doorstéken, two meanings and two Modern Dutch forms are given in Table 4. The second meaning ('to wound') can be seen as a specialisation of the more general first one ('to stab completely through') and only occurs in very specific contexts. ${ }^{9}$

Inspection of the ICVs with over shows a similar result. The $10 \mathrm{ICVs}$ with over from our corpus and their Modern Dutch counterparts are listed in Table 5.

9 This ICV is mainly found in tales of chivalry and expresses the act of wounding someone (by stabbing him) in a combat, while both the actor and the victim are sitting on horses. In these contexts, the best translation of this complex verb seems to be 'to wound' (in Modern Dutch verwonden). 
Table 5

Middle Dutch ICVs with over

\begin{tabular}{ll}
\hline MidDle DuTCH & MODERN DUTCH \\
\hline $\begin{array}{l}\text { overdrágen 'to agree, to decide' } \\
\text { overdénken 'to think over completely, to reflect on' }\end{array}$ & besluiten \\
overhángen 'to hang (with), to decorate with' & behangen \\
overláden 'to overload' & id. \\
overláechen 'to overload' & overláden \\
overlásten 'to attack' & overvállen \\
overlópen 1 'to surprise, to attack' & overvállen \\
overlópen met 2 'to suffuse with' & overgíeten met \\
overspréken 'to discuss, to talk about fully' & bespreken \\
overvállen 'to surprise, to attack' & id. \\
\hline
\end{tabular}

Again, there are no ICVs that have developed into Modern Dutch SCVs, in conformity with our hypothesis.

We see some Middle Dutch ICVs remaining the same in Modern Dutch (same form, same function, e.g. overvállen, overdénken), whereas other ICVs are replaced with an etymologically related ICV with the same meaning (overláechen, overlópen 1 and 2), or with an ICV that is not immediately recognizable as etymologically related to the Middle Dutch form (overdrágen).

Furthermore, there are two ICVs in which the prefix over is replaced with the prefix be-(overhángen, overspréken). This prefix is, just like ver-, transitivizing and holistic and thus semantically similar to inseparable over (and door). Since inseparable over and door could, in written language, be confused with their separable counterparts, it might be preferable to use the be- or ver- variant of a verb. As a consequence, complex verbs with over and door could have become obsolete. To asses the validity of this account, however, the semantic properties of $b e$ - and ver- should be studied more carefully in order to check whether these prefixes indeed resemble inseparable door and over in all relevant aspects.

In all cases, both the Middle and the Modern Dutch ICVs show the holistic interpretation and the total affectedness of the direct object, as expected.

To summarize, Middle Dutch ICVs are still ICVs in Modern Dutch or have developed into ICVs with similar forms and the same meaning. In any case, there are no Middle Dutch ICVs that have developed into SCVs. Our diachronic hypothesis, then, is convincingly confirmed by the data. 


\subsubsection{Middle Dutch complex verbs with both SCV and ICV behaviour}

Our corpus contains seven complex verbs that show both SCV behaviour and ICV behaviour. Three of these, namely doorzoeken 'to search completely', doorscrepen 'to scrape off completely', and overbrengen 'to use up, to squander (time/goods)', are holistic in meaning and have preverbs without independent semantic content. (47) shows examples of the verb doorzoeken, both as SCV (the a-example) and as ICV (the b-example). ${ }^{10}$

(47) (a) Doe sochten si veel rijken ende landen doer (II-4b)

then searched they many states and countries through

'Then they searched many states and countries.'

(b) waer op wi den hemel ende sterren doersocht hebben (II-5b)

where up we the sky and stars through-searched have

'after which we searched the sky and the stars'

These verbs seem to pose a puzzle for the (synchronic) semantic-syntactic parallel, since they seem to have an SCV and an ICV variant with one and the same meaning. This formal variation, however, can be readily understood from a diachronic perspective. The holistic meanings of both verbs indicate that the semantic change from preverb with independent semantic content into one without it has already taken place. Apparently, this semantic change has not yet led to a fully systematic change in formal structure, changing the separable verb into an inseparable one. Instead, there is (temporary) variation: both the separable and the inseparable form are used. As language variation is assumed to be the first step in language change, this variation can be accounted for by assuming these data to reflect the syntactic change in progress.

In Modern Dutch, however, the variation is eliminated: the Modern Dutch verb doorzóeken 'to search completely' functions as an ICV, so the formal change is completed in Modern Dutch. The fact that this Modern Dutch verb is an ICV supports the claim that the verb was indeed changing in this direction in Middle Dutch.

The four other complex verbs that show both SCV and ICV behaviour in Middle Dutch do not have holistic meanings, but instead, clearly show SCV meanings. This concerns the verbs overkomen 'to come over', overliden 'to pass by', overlezen 'to read through, to read aloud', and overzetten 'to

10 Although the past participial marker ge- is not consistently used in Middle Dutch (see 4.1), it is so in the text from which example (47b) comes. Therefore, the absence of ge- in doersocht can be taken as ICV evidence. 
transpose, to edit, to translate'. None of these complex verbs shows the ICV semantics of total affectedness. Some examples of these verbs, both separated (a) and non-separated (b), are given in (48)-(49).

(48) (a) dat haer here aldus was ouerghecomen (I-152rb)

that their lord thus was over-ghe-come

'that their lord thus had come over'

(b) mijn wijf is mi ouercomen van minen lande (II-58b)

my wife is me over-come from my land

'my wife has come over to me from my land'

(49) (a) eist dat hise oec onderwilen niet ouer en leest (IVa-182)

is-it that hi-them also meanwhile not $\overline{\text { over }}$ en reads

'if it is the case that he does not even read them through/read them aloud meanwhile'

(b) wat van godliken scriften te ouerlesen (III-102e)

something from religious writings te $\overline{\text { over-read }}$

'to read through/read aloud something from religious writings'

Synchronically, for these verbs one and the same meaning corresponds to two different forms. Because of their SCV semantics, these verbs are also difficult to account for from a diachronic viewpoint, since we claim that semantic changes trigger, and hence precede, formal changes. In these verbs, no semantic change seems to have taken place, so it is unclear why there should be a formal change in progress at all.

Two of the four verbs, overkomen and overliden, have formal ICV variants in both Middle and Modern Dutch and have several meanings, at least in Middle Dutch. However, no strictly minimal pairs exist in Middle Dutch, in the sense that one form (separable versus inseparable) corresponds to one meaning (SCV meaning versus ICV meaning). Apparently, though, meanings were changing and the resulting polysemy, together with the existing SCVs and ICVs with their typical SCV and ICV meanings, could have brought about this variation with respect to the forms of verbs such as overkomen and overliden.

As for overkomen 'to come over', there indeed seems to be a lot of formal and semantic variation in Middle Dutch. Our corpus contains two lemmas of overkomen: one with non-holistic semantics, meaning 'to come over', in which the preverb has independent semantic content, and one with holistic semantics, meaning 'to happen to'. However, there does not seem to be a clear formal difference correlating with these two meanings. The non-holistic meaning occurs in both separable and inseparable forms, whereas the holistic 
meaning, which occurs only once, is found in a separable form. ${ }^{11}$ In Modern Dutch, this variation is, again, eliminated: whereas separable óverkomen consistently means 'to come over', inseparable overkómen consistently means 'to happen to'.

Overliden 'to pass by' does not exist in Modern Dutch anymore. The base verb liden 'to go' has disappeared and is replaced by the Modern Dutch verb gaan, so that the meaning 'to pass by' nowadays is conveyed by the form óvergaan. There is, however, still an inseparable and holistic variant of the older form overliden, namely overlijden, meaning 'to die', which also exists in Middle Dutch. We thus see that there has been bleaching of the original meaning, which has brought about a holistic interpretation, and that, in parallel to these semantic changes, the change of becoming an ICV has taken place. This verb, then, fits perfectly in our grammaticalization cline and confirms our diachronic hypothesis, although we find some temporary "mismatches" in the Middle Dutch forms, probably due to variation and changes being in progress.

Evidence for the role that polysemy may have played and for the tendency of speakers to pair one form with one meaning is provided by the fact that the polysemy of these verbs has disappeared in Modern Dutch. Whereas these four Middle Dutch verbs all have more than one meaning, their Modern Dutch counterparts pair the different meanings with different forms. We already saw this in overkomen, and we can also observe it in, for example, overlezen: the two meanings 'to read through' and 'to read aloud' (see the examples in (49) above) are expressed by two different forms in Modern Dutch (by overlezen and hardop lezen respectively).

\section{Conclusions}

In this paper we proposed an analysis of SCVs as constructional idioms. According to this analysis, the SCV system may function as an intermediate stage in the grammaticalization of syntactic constructions (secondary predicates, adverb-verb combinations) into morphological constructions (prefixed words, ICVs). This proposal implies that SCVs develop into ICVs, but not vice versa.

11 This holistic, but separated, verb probably shows the semantic development anticipating the syntactic development, as is discussed in section 4.2.3. 
The unidirectional development of SCVs into ICVs has two components: a semantic and a formal side. We hypothesized that semantic changes trigger the formal change of SCV into ICV. The data of our corpus confirmed this.

First, there is a synchronic relation between the separability of a preverb and its semantic content. That is, both the Middle and the Modern Dutch data show that separable preverbs have more independent semantic content than inseparable preverbs, while the latter impose holistic interpretations on the complex verbs they form. ICV preverbs, then, form close semantic units with their verbs and express, together with these verbal bases, the total affectedness of the direct object.

Diachronically, we found a parallel between the semantic and the syntactic development of the preverbs, in the sense that the semantic changes just mentioned lead to the loss of syntactic independence. Although most Middle Dutch SCVs are still SCVs in Modern Dutch and many Middle Dutch ICVs still function as ICVs in Modern Dutch, we also saw changes regarding the separability of the complex verbs. If such a (structural) change takes place, it is only in one direction: SCVs develop into ICVs, but not vice versa. Moreover, this syntactic change is preceded by the expected semantic changes, which are also unidirectional: if there is a semantic change, it is only in one direction, namely a change from a preverb that has independent semantic content into one that has no clear content of its own (semantic bleaching), but merely imposes a holistic meaning on the complex verb as a whole.

It should be noted, however, that only a small subset of the Middle Dutch SCVs in our corpus have actually developed into Modern Dutch ICVs. Apparently, then, the SCV system is a relatively stable system, although SCVs may function as intermediate stages in the grammaticalization of syntactic structures into words, being constructional idioms.

Future research should deal with more data, not only comprising complex verbs with the preverbs door and over, but also with other preverbs, to see whether the results of the present research can be generalized to other particles and prefixes. Another issue that should be addressed concerns the chronological and geographical variance among the Middle Dutch data. No claims regarding this point can be made on the basis of our data, since our corpus is too small to split the data according to time and place of origin.

What the present study clearly reveals, however, is that, for an SCV to become an ICV, there first have to be changes in the semantic content of the preverb in the relevant construction, leading to a holistic meaning, since it is only after such changes that there is a trigger for changing the structure of the complex verb. We saw some examples of the semantic change preceding 
the syntactic change: some preverbs of Middle Dutch SCVs have holistic meanings, whereas their structure is not adjusted to this semantic change until in the Modern Dutch period, changing these SCVs into ICVs.

\section{References}

Corpus texts:

CD-ROM Middelnederlands [CD-ROM Middle Dutch] 1998. Sdu/Standaard, The Hague \& Antwerp.

I. Historie van Troyen (1479, Gouda, 27,346 words)

II. Historie van die seuen wijse mannen van roemen (1480, Gouda, 39,000 words)

III. Van duytsche boeken te lesen (1445, Eastern Flanders, Brabant, 3,425 words)

IV. Verclaringhe vanden duytschen boeken (excerpten) (1460, Eastern Flanders, Brabant, 3,091 words)

V. Historie van Reynaert die vos (1479, Gouda, 48,707 words)

VI. Historie van Malegijs (1556, Antwerp, 104,323 words)

VII. Brieven (1350, Gent, 28,851 words)

VIII. Cyrurgie (1351, Flanders, 88,042 words)

IX. Boek van Medicinen (1351, Flanders, 27,377)

X. Chiromantie (1351, Western part of the Low Countries, 4,669 words)

XI. Leringhe van orinen, Uroscopie (1351, Flanders, 9,350 words)

XII. Liber Magistri Avicenne (1351, 24,776 words)

XIII. Spiegel der sonden (1435, Oudenaarde, Western-Gelderland, 66,496 words)

Ackerman, Farrell-Pierre LeSourd 1997. Towards a lexical representation of phrasal predicates. In: Alex Alsina - Joan Bresnan - Peter Sells (eds) Complex predicates, 67-106. CSLI Publications, Stanford CA.

Ackerman, Farrell-Gerd Webelhuth 1998. A theory of predicates. CSLI Publications, Stanford CA.

Blom, Corrien 2002. Word order in Middle Dutch: the interpretation of different types of data. In: Hans Broekhuis - Paula Fikkert (eds) Linguistics in the Netherlands 2002 (AVT Publications 19), 13-24. John Benjamins, Amsterdam \& Philadelphia.

Booij, Geert 2002a. The morphology of Dutch. Oxford University Press, Oxford.

Booij, Geert 2002b. Separable complex verbs in Dutch: a case of periphrastic word formation. In: Nicole Dehé - Ray Jackendoff - Andrew McIntyre - Silke Urban (eds) Verb-particle explorations, 21-41. Mouton de Gruyter, Berlin \& New York.

Bresnan, Joan-Sam Mchombo 1995. The lexical integrity principle: evidence from Bantu. In: Natural Language and Linguistic Theory $13: 181-254$.

Campbell, Lyle 2001. What's wrong with grammaticalization? In: Language Sciences 23: 113-61.

Harris, Alice 2003. Preverb location and dislocation. In: Geert Booij- Jaap van Marle (eds) Yearbook of Morphology 2003. Kluwer, Dordrecht.

Hoeksema, Jack 1991a. Complex predicates and liberation. In: Linguistics and Philosophy 14: $661-710$.

Acta Linguistica Hungarica 50, 2003 
Hoeksema, Jack 1991b. Theoretische aspecten van partikelvooropplaatsing [Theoretical aspects of particle preposing]. In: TABU $21: 18-26$.

Hopper, Paul-Elizabeth Traugott 1993. Grammaticalization. Cambridge University Press, Cambridge.

Horst, Jack van der-Kees van der Horst 1999. Geschiedenis van het Nederlands in de twintigste eeuw [History of Dutch in the twentieth century]. Sdu, The Hague.

Jackendoff, Ray 1997. The architecture of the language faculty. MIT Press, Cambridge MA.

Lapointe, Steven 1980. A theory of grammatical agreement. Ph.D. thesis, University of Massachusetts, Amherst. (Also published by Garland, New York in 1985.)

Loey, Adolphe van 1976. Scheidbare en onscheidbare werkwoorden hoofdzakelijk in het Middelnederlands, analytische studiën [Separable and inseparable verbs principally in Middle Dutch, analytical studies]. Secretary of the Royal Academy of Dutch language and literature, Gent.

Los, Bettelou 2002. Complex predicates in English and Dutch. Paper presented at the YorkHolland Symposium, University of York, April 20.

Lüdeling, Anke 1999. On particle verbs and similar constructions in German. CSLI Publications, Stanford CA.

MNW 1998. Middelnederlandsch Woordenboek, CD-ROM Middelnederlands [Middle Dutch Dictionary, CD-ROM Middle Dutch]. Sdu/Standard, The Hague \& Antwerp.

Stiebels, Barbara-Dieter Wunderlich 1994. Morphology feeds syntax: the case of particle verbs. In: Linguistics 32:913-68.

Watkins, Calvert 1964. Preliminaries to the reconstruction of Indo-European sentence structure. In: Horace D. Lunt (ed.) Proceedings of the 9th International Congress of Linguists, 1035-44. Mouton, Berlin \& New York.

Address of the authors: Corrien Blom-Geert Booij

Department of Linguistics

Free University Amsterdam

De Boelelaan 1105

1081 HV Amsterdam

Netherlands

\{c.blom|ge.booij\}@let.vu.nl 